\title{
Mixed Squamous Cell Carcinoma of the Penis
}

National Cancer Institute

\section{Source}

National Cancer Institute. Mixed Squamous Cell Carcinoma of the Penis. NCI Thesaurus. Code C39959.

A squamous cell carcinoma that arises from the penis and is characterized by a mixture of morphologic patterns (e.g., high grade squamous cell carcinoma and verrucous carcinoma or warty-basaloid carcinoma). 